\title{
Viewpoint
}

\section{Why take up rheumatology?}

Some years ago I spent many hours every year sitting on boards interviewing would-be medical students, and almost inevitably some member of the committee would round on the unfortunate boy or girl and ask what made them decide to take up medicine. The usual answer, thought up well beforehand as they knew this question was likely to be asked, was usually because they loved 'people' and wished to help them and so on. Members of the committee usually shifted uneasily in their chairs at this, as they had half-hoped for a rather more original (or possibly truthful) answer. The best reply I ever had was from an Arab youth who answered, 'Because it is not without interest and carries financial security.' I accepted him on that truthful answer, but alas', the political scene in his country changed and he never came back.

Before I personally took up medicine I made out a 7-point plan to show my father, partly to convince him that I really didn't want to go into the Church (he was a Canon in the Church of England) nor into the Law, like my senior uncle. My 7 points as far as I can remember them after all this time were: (1) In medicine one dealt with people, primarily, and the idea of helping your fellow man and preserving his life and health rather than taking his money or killing him appealed quite strongly to me. (2) If there was a war you didn't have to kill anybody but went on as under (1). (3) It was extraordinarily interesting and highly practical in its application. (4) Once qualified one had a huge range of different careers from which to pick. One could be a surgeon, a physician, a psychiatrist, a pathologist, a public health official, and so on. There was almost no end to the range of jobs one could do. (5) As a doctor of medicine one's work was universal and many parts of the world in those days were open to one. (6) There were great opportunities for research and study and specialisation. (7) Although the main idea was not to make money (or one would have gone into business or finance) the work did, as my Arab student said, carry financial security, and also a position in society which was, in general, looked up to and respected.

These 7 points in general still hold, though in some ways perhaps not quite so strongly as before. But from the very beginning how right $I$ was! The joy of scientific studies, new to one as a medical student, the drama and interest of the clinical studies. One flirted with anatomy, surgery, paediatrics, chest medicine, endocrinology, and finally got married to rheumatology, a huge subject not even considered to be a specialty in those prewar days. As a student the only connective tissue disorders I ever saw were rheumatic fever and (very rarely in the outpatient clinic) gout. In those days in Edinburgh, before Professor Stanley Davidson had arrived and appointed Ian Duthie, there was no apparent rheumatology and certainly no rheumatologist. Even in these more enlightened days, considering the size of the field and the magnitude of the problem, there are not nearly enough to go round.

So, why be a rheumatologist? Here would be my 7 points in answer to this question to-day.

(1) It runs right through the whole field of general medicine. He who really knows the rheumatic disorders knows a very great deal of medicine.

(2) It is a huge clinical, therapeutic, social, and research challenge. Like Guinness, there's a lot of it about, and the field for research in all aspects is wide open.

(3) You meet such a nice lot of people as patients and colleagues. It is a constant wonder to me how brave and stoical most rheumatic sufferers are. In clinical medicine in general and perhaps in rheumatology in particular you can make two new friends every day.

(4) The world is your oyster. Rheumatology is everywhere but strikingly different in different races and countries, and in most countries the subject is virtually untapped, and the rheumatic disorders an unopened book.

(5) Therapeutically it covers a wider field than most specialties, dealing with pharmacology, physical, social and occupational medicine, surgery, nursing, immunology, chiropody, etc. The therapeutic team is a large one, the rheumatologist being the central figure and co-ordinator in chief, though the general practitioner has the difficult job of making it all come together, as it were, in the patient's home.

(6) In the diagnosis and treatment of most rheumatic conditions rheumatology makes great demands 
on one. There are around 180 conditions to be considered in the differential diagnosis of any socalled rheumatic disorder.

(7) In the management and treatment of the more chronic and intractable rheumatic diseases one has to be a mixture of a good psychologist, an applied pharmacologist, have a practical knowledge of physical and occupational methods, be a respected father confessor cum general physician, in fact be a wide-spectrum and sympathetic therapist. A cowboy could cure penicillin sensitive pneumococcal pneu-

\section{Correspondence}

\section{Septic arthritis due to Pasteurella multocida}

Sir,

I read with interest the recent report of septic arthritis due to Pasteurella multocida. ${ }^{1}$ Although Pasteurella is mentioned rarely as a cause of gram-negative pyogenic arthritis, ${ }^{2}$ its occurrence has been documented previously in normal individuals as well as patients with rheumatoid arthritis. ${ }^{3}$ The illness is associated with an animal bite or scratch in most cases and responds favorably to prolonged antibiotic therapy, usually with penicillin G.

The demonstration by Williams and Fincham of disease due to a resistant $P$. multocida raises an important issue regarding therapy for animal bites and related infections. Most $P$. multocida are extremely sensitive in vitro to penicillin G. ${ }^{4}$ However, we also have observed relative resistance to penicillin $\mathrm{G}$ demonstrated by minimum inhibitory concentrations in several isolates from patients with severe infections such as osteomyelitis. ${ }^{5}$ These observations argue for sensitivity testing of $P$. multocida isolates in cases where response to penicillin therapy is not optimal. Furthermore, failure of prophylactic therapy with moderate doses of penicillin also should raise the possibility of resistant organisms.

Philip J. Spagnuolo, Division of Infectious Disease, Veterans Adminstration Hospital, Cleveland, Ohio, USA

\section{References}

1 Williams R A, Fincham W J. Septic arthritis due to Pasteurella multocida complicating rheumatoid arthritis. Ann Rheum Dis 1979; 38: 394-5.

2 Goldenberg D L, Cohen A S. Acute infectious arthritis, a review of patients with nongonoccal joint infection. Am J Med 1976; 60: 369-77.

3 Spagnuolo P J. Pasteurella multocida infectious arthritis. Am J Med Sci 1978; 275: 359-63. monia if he had access to the right drug, but it takes a proper doctor to treat and manage rheumatoid arthritis.

So for a young energetic man with a touch of the explorer or the missionary (or both) in him, here is your challenge. Your research may get nowhere, your new drugs may fail, your back may ache abominably towards the end of the clinic, but oh boy was it worth it? Yes, indeed. A thousand times yes!

F. DUDLEY HART

4 Rosenthal S L, Freundlich L F. In virto antibiotic sensitivity of Pasteurella multocida. Health Lab Sci 1976 13: 246-9.

5 Spagnuolo P J, Friedman R I. Penicillin sensitivity of invasive and non-invasive Pasteurella multocida. J. Antimicrob Chemother 1979; 5: 324-5.

\section{Gold and penicillamine}

Sir,

In their article Pritchard and Nuki ${ }^{1}$ expressed the opinion that D-penicillamine and gold, because of the sulphydryl groups, may have the same mode of action in the therapy of rheumatoid arthritis. In our opinion this would appear highly unlikely to be the effect of gold preparations, even when they are complex salts of acids containing $\mathrm{SH}$ groups. The gold which in such complex salts replaces the hydrogen atom of the $\mathrm{SH}$ group is firmly bound there. As a result, the concentration of free $\mathrm{SH}$ groups, present in equilibrium, is so small that it cannot possibly play an important role when compared with the therapy using other substances containing $\mathrm{SH}$ groups. But even if we regard the total $\mathrm{S}$ in the gold preparations as potential $\mathrm{SH}$ groups, the amount of $\mathrm{SH}$-groups given during penicillamine treatment is of a much higher order of magnitude than the $\mathrm{SH}$ groups given during gold therapy.

I. TAUTZ Bayer $A G$, Pharma Forschungszentrum, Ressort Medizin, Aprather Weg, Postfach 1017 09, D-5600 Wuppertal 1, West Germany

\section{Reference}

1 Pritchard M H, Nuki G. Gold and penicillamine: a proposed mode of action in rheumatoid arthritis, based on synovial fluid analysis. Ann Rheum Dis 1979; 38: 493-503. 